\title{
COVID-19 and Transnational Issues in Copyright and Related Rights
}

\author{
Marketa Trimble
}

Published online: 4 May 2020

(C) Max Planck Institute for Innovation and Competition, Munich 2020

The realities of a world battling COVID-19 have forced entire nations to rely - more than ever before - on the internet for communication, work, commerce, education, and entertainment. This increased reliance has intensified the need to find answers to many questions regarding the copyright law implications of actions on the internet. For instance, because of the sudden switch to online education that COVID-19related restrictions have caused, many educators have been wondering how copyright law exceptions and limitations might apply differently when they teach online rather than when they teach in-person in a classroom.

The answers to educators' copyright questions might have been relatively straightforward for purely single-country scenarios - though with the caveats usual in any legal matters as complex as copyright. However, the answers are substantially more complicated in two- or multiple-country scenarios. Reproducing a short clip from a motion picture in a presentation that is made available to the public online might be permissible under a copyright exception or limitation in one country (perhaps under a fair use doctrine), but not necessarily permissible under a copyright exception in another country (under a quotation exception, for example). Which country's law governs in this scenario and what might be the practical repercussions of the action are difficult questions.

The COVID-19 situation is a wakeup call on many fronts, and the importance of many of the issues that COVID-19 has brought to the attention of humanity certainly eclipses the importance of any copyright law issues that have been highlighted by the situation. But to the extent that the situation provides a sensible lesson for copyright law, the lesson is that a comprehensive review of transnational issues in copyright law is warranted to address questions such as those arising in the scenario above.

\section{Trimble $(\bowtie)$}

Samuel S. Lionel Professor of Intellectual Property Law, William S. Boyd School of Law, University of Nevada, Las Vegas, USA

e-mail: marketa.trimble@unlv.edu 
Countries and the international community as a whole have not heretofore completely ignored transnational copyright issues. In principle, national legislatures seldom consider the transnational aspects of copyright matters in legislation, but instances exist in which they have legislated on these aspects. For example, the German Act on Copyright and Related Rights establishes the Act's provisions on equitable remuneration as internationally mandatory rules, the Portuguese Civil Code provides a choice-of-law rule for copyright ownership, and - as many countries' copyright statutes do - the U.S. Copyright Act prohibits the importation and exportation of copyright-infringing copies and phonorecords.

Recent international-level attempts at addressing transnational copyright issues have been sporadic and not notably successful. The negotiators of the TRIPS Agreement could not agree on a provision on transfer of rights that, as Hannu Wager recalled, "raised difficult questions concerning the law applicable to the determination of authorship and the validity of contractual agreements." ${ }^{1}$ In her description of the Beijing Treaty negotiations Silke von Lewinski referred to the continuing difficulties in international negotiations with respect to the transnational aspects of transfers of rights. These difficulties prevented the adoption of a treaty on the protection of audiovisual performances in 2000 and influenced the negotiations and the final text of the Beijing Treaty. ${ }^{2}$ Even the negotiators of the Marrakesh Treaty who, as Mihály Ficsor noted, recognized the importance of the Treaty's provisions on the cross-border exchange of accessible format copies, shied away from addressing the complex choice-of-law issues that the cross-border exchange regime implicates. ${ }^{3}$

In the European Union, achievements in addressing transnational copyright matters in copyright law instruments have been - perhaps surprisingly - somewhat modest. The SatCab Directive and its amending Directive provide a rule for a particular localization of the act of communication to the public in cases of satellite broadcasts and ancillary online services; the localization affects the determination of the law applicable to transnational cases. ${ }^{4}$ The EU Orphan Works Directive provides for mutual recognition by EU Member States of the status of the orphan

\footnotetext{
${ }^{1}$ Hannu Wager, "Copyright: A Nordic Perspective", in "The Making of the TRIPS Agreement: Personal Insights from the Uruguay Round Negotiations", Jayashree Watal and Antony Taubman eds. World Trade Organization 2015, pp. 321-339, p. 326.

2 Silke von Lewinski, "The Beijing Treaty on Audiovisual Performances", Max Planck Institute for Intellectual Property and Competition Law Research Paper No. 13-08, 2013; Background Document on the Main Questions and Positions Concerning the International Protection on Audiovisual Performances, WIPO, SCCR/19/9, 30 November 2010, p. 4, par. 9.

3 M.J. Ficsor, "Commentary on the Marrakesh Treaty on Accessible Format Copies for the Visually Impaired, Copyright See-Saw", 11 October 2013. On the conflict-of-laws issues in the Marrakesh Treaty cross-border exchange regime see Marketa Trimble, "The Marrakesh Puzzle", 45(7) IIC 768 (2014).

4 Council Directive 93/83/EEC of 27 September 1993 on the coordination of certain rules concerning copyright and rights related to copyright applicable to satellite broadcasting and cable retransmission, Art. 1(2)(b); Directive (EU) 2019/789 of the European Parliament and of the Council of 17 April 2019 laying down rules on the exercise of copyright and related rights applicable to certain online transmissions of broadcasting organisations and retransmissions of television and radio programmes, and amending Council Directive 93/83/EEC, Art. 3(1)(b).
} 
work. $^{5}$ Other EU instruments that refer to cross-border matters are the EU Collective Management Directive (the provisions that concern multi-territorial licensing of rights in musical works for online use) and the EU Digital Single Market Directive (the provisions that concern cross-border teaching activities and cross-border use of out-of-commerce works). ${ }^{6}$

In addition to the solutions in substantive copyright law provisions, conflict-oflaws provisions may provide solutions to transnational problems. The harmonization of countries' substantive laws ensures that any differences among the laws are nonexistent, or at least sufficiently minor so that the transnational nature of any issues is irrelevant: the application of any country's law will produce results identical or similar to those produced by the application of any other country's laws. Conflict-of-laws solutions build on the recognition that countries' laws vary and/or that the application of the laws may lead to different results; conflict-of-laws rules establish the signposts that are necessary to determine jurisdiction and applicable law and the recognition and enforcement of foreign judgments. But only when conflict-of-laws rules are harmonized among countries do the rules truly resolve transnational issues effectively.

Countries have harmonized some of their conflict-of-laws rules that affect copyright cases. The U.N. Convention on the Recognition and Enforcement of Foreign Arbitral Awards covers arbitral awards made in copyright cases, and The Hague Conference Convention on Choice of Court Agreements covers copyright cases. But when the multi-year efforts of The Hague Conference on Private International Law culminated in 2019 in the conclusion of the Convention on the Recognition and Enforcement of Foreign Judgments, the Convention negotiators excluded intellectual property matters, including copyright matters, from the scope of the Convention. ${ }^{7}$

The fact that EU Member States have been able to agree among themselves on conflict-of-laws rules, including for copyright cases, confirms the connection between the substantive law harmonization and conflict-of-laws solutions to transnational issues ${ }^{8}$ : When countries' substantive laws are sufficiently similar, countries are more likely to agree on conflict-of-laws rules, but when the laws are significantly different, countries are less likely to agree on the rules. Jane Ginsburg and André Lucas crystallized the issue in their Study on Transfer of the Rights of

\footnotetext{
${ }^{5}$ Directive 2012/28/EU of the European Parliament and of the Council of 25 October 2012 on certain permitted uses of orphan works, Art. 4.

6 Directive 2014/26/EU of the European Parliament and of the Council of 26 February 2014 on collective management of copyright and related rights and multi-territorial licensing of rights in musical works for online use in the internal market, Title III; Directive (EU) 2019/790 of the European Parliament and of the Council of 17 April 2019 on copyright and related rights in the Digital Single Market and amending Directives 96/9/EC and 2001/29/EC, Arts. 5, 8, and 9.

7 Convention on the Recognition and Enforcement of Foreign Judgments in Civil or Commercial Matters, 2 July 2019, Art. 2(1)(m).

${ }^{8} \mathrm{EU}$ choice-of-law instruments include a rule governing the choice of law applicable to copyright infringement but not a rule governing the choice of law applicable to copyright ownership, thus allowing for differences in EU member states' choice-of-law rules in that respect. Regulation (EC) No 864/2007 of the European Parliament and of the Council of 11 July 2007 on the law applicable to non-contractual obligations (Rome II), Art. 8.
} 
Performers to Producers of Audiovisual Fixations: "It would be easier to resolve questions of applicable law if the process of substantive harmonization were more advanced." 9

Nevertheless, the connection between the two types of solutions does not mean that progress in resolving transnational issues depends on the harmonization of substantive laws. Countries could first turn their attention to conflict-of-laws solutions and seek progress on the harmonization of substantive copyright law later, if at all. There are three reasons to focus on conflict-of-laws solutions at this point. First, to the extent that countries might have reached for now the limits of international copyright law harmonization, conflict-of-laws rules remain the only option for countries to advance solutions to transnational copyright issues. Second, even if complete substantive harmonization were possible and countries had identical statutes, interpretations of the statutes and procedural rules and practices in the countries would differ and would perpetuate discrepancies among the countries' laws, thus necessitating conflict-of-laws solutions to transnational issues. Finally, a robust body of literature by authors from various countries has analyzed the intersection of conflict of laws and copyright law, and the literature forms a useful basis for discussion and development of proposals for conflict-of-laws solutions.

Conflict-of-laws solutions cannot eliminate the major differences that persist among countries' views on substantive law. In copyright law some of the major differences are linked to countries' positions on fundamental human rights and other significant interests, which make the differences particularly difficult to reconcile internationally. But the conflict-of-laws field offers tools, most notably the public policy exception, that enable conflict-of-laws rules to operate while respecting the major differences among countries' laws. The application of conflict-of-laws rules offers opportunities to learn about and appreciate the differences in and underpinnings of countries' substantive laws and gradually resolve some of the differences. Legal certainty with regard to internet activities would improve significantly if conflict-of-rules could be harmonized internationally.

Publisher's Note Springer Nature remains neutral with regard to jurisdictional claims in published maps and institutional affiliations.

\footnotetext{
9 Jane C. Ginsburg and André Lucas, "Study on Transfer of the Rights of Performers to Producers of Audiovisual Fixations - Conclusion”, WIPO, AVP/IM/03/4 Add., 12 May 2004, p. 7, para. 4.
} 